\title{
Causes of Domestic Terrorism: Economic Sanctions as a Violence Trigger Structure
}

\author{
Seung-Whan Choi
}

\begin{abstract}
This study examines whether the imposition of economic sanctions has relation to an increase in domestic terrorism, postulating that when sanctions impair the economic functioning of the target country, feelings of bitterness and despair are intensified among the poor who may then lash out by turning to domestic terrorism. A cross-sectional, time-series data analysis of 152 countries over the past three decades provides evidence that ceteris paribus, economic sanctions are positively associated with the incidence of domestic terror; this effect remains when reverse causality is taken into account. In order to clarify the role of poverty in this association, this study also introduces a two-step analysis in which sanctions are first considered a cause of poverty, and then predicted poverty levels are used to predict the occurrence of terrorism. This test for robustness confirms that economic sanctions do indeed lead to a rise in the rate of domestic terrorism.
\end{abstract}

Key Words: economic sanctions, terrorism, domestic terrorism, poverty

\begin{abstract}
Sanctions and humanitarianism often collide. Although in theory sanctions are motivated by an implicitly humane rationale, their implementation often wreaks great havoc and civilian suffering. Inherent in sanctions policy are uncomfortable and, for the moment, still imprecise calculations about inflicting civilian pain to achieve political gain (Weiss et al. 1997, 30).
\end{abstract}

I t seems almost intuitive to explain terrorism in terms of poverty because, we suppose, when people are desperate and find no more economic opportunities before them, they will be predisposed to commit terrorist violence in an effort to voice their demands; indeed, many journalists and policy-makers frequently think of terrorism as a result of poverty. For example, Halperin ${ }^{1}$, Siegle, and

\footnotetext{
*Seung-Whan Choi (whanchoi@gmail.com) is Associate Professor in the Department of Political Science at the University of Illinois, Chicago. His research interests include international conflict, democracy, terrorism, globalization, and methodology. His work has been published in journals such as the American Journal of Political Science, British Journal of Political Science, International Studies Quarterly, Journal of Conflict Resolution, Journal of Peace Research, and elsewhere. He is author of A New Quest for International Peace: Civil-Military Dynamics, Political Communications and Democracy (Palgrave 2005).
}

The Korean Journal of International Studies Vol.12-1 (June 2014), 137-159.

http://dx.doi.org/10.14731/kjis.2014.06.12.1.137

(c) 2014 The Korean Association of International Studies 
Weistein $(2005,121)$ argue that "autocracy, conflict, and poverty are all factors in the growth of militant Islamic terrorism." Yet, the scholarly literature largely dismiss poverty as a cause of terrorism and instead looks at factors such as regime type, economic development, and state failure (e.g., Enders and Sandler 2006). There are, however, some recent studies that find supporting evidence for the relationship between poverty and terrorism. Lai's (2007) research, for example, shows that economic inequality leads to an increase of terrorism; Piazza's (2011) recent work also demonstrates that countries displaying minority group economic discrimination are more vulnerable to domestic terrorism because groups suffering from economic pain turn to violence in retribution. What these empirical studies have in common is that they trace the origins of terrorism back to internal factors such as economic discrimination rather than to factors originating outside of the terror-prone country. This study, in contrast, argues that the imposition of economic sanctions is an external shock that triggers domestic terrorism: more specifically, it posits that sanctions worsen poverty which, in turn, motivates acts of domestic terrorism.

Economic sanctions are a foreign policy tool intended to coerce target governments into particular avenues of positive response. For example, economic sanctions may be imposed in the effort to dissuade a target country's authoritarian tendencies or human rights abuses (Peksen 2009). However, this study argues that sanctions may also create unexpected side effects; that is, it shows how economic coercion unintentionally yields increased terrorist activity within the sanctioned countries. Because economic sanctions are designed to impair the economic capability of the target country, those put at the greatest risk are not the authoritarian leader and key supporters, but the poorest segments of the population. While the country initiating sanctions has no incentive to intensify feelings of hopelessness among the poor of the sanctioned country, it may unintentionally push these people into such a position, ultimately provoking them to terrorist violence in desperation. ${ }^{2}$ Consequently, it is the poor rather than the powerful who are the primary victims of economic sanctions and, thus, who may resort to domestic terrorism out of a sense of despair.

\footnotetext{
${ }^{1}$ Morton H. Halperin has a distinguished career in federal government, having served in the Clinton, Nixon, and Johnson administrations. He is currently a senior advisor to the Open Society Foundations, accessed at www.opensocietyfoundations.org/people/morton-halperin.

${ }^{2}$ This study believes that increased terrorism is a counterproductive effect of economic sanctions because economic hardships inflicted on the poor do not necessarily translate into support for the sanctioning country. For example, regarding the economic sanctions that have been imposed by the United States since 1979, "the Gallup poll reported that only 8\% of Iranians approve of U.S. leadership. Many Iranians blame the U.S. and the West for the state of their economy” (Schilmoeller 2012).
} 
Based on a sample of 152 countries over the period from 1970 to 2004, this study is the first quantitative research to examine how economic sanctions are associated with domestic terrorism. At the outset, it should be noted that the sanctions-international terrorism connection is beyond the scope of this study as it is a new research project requiring a different causal explanation and empirical model. Instead, this study presents a causal mechanism in which economic sanctions are conceptualized as "a violence trigger structure" that intensifies the despair of poor people who may, then, employ terrorist violence against domestic targets in order to avenge feelings of anger and frustration (see Gurr 1970; Weiss 1999; Rowe 2001; Allen 2008; Wood 2008). Specifically, this study argues that because economic sanctions primarily impact poor people in the affected country, they cause feelings of deprivation and bitterness which can function as a breeding ground for terrorism; this anger is often directed towards the government and its key supporters, in the form of domestic terrorism.

A cross-sectional, time-series data analysis shows that, all other things being equal, economic sanctions lead to an increase in domestic terrorism; furthermore, this finding is consistent, irrespective of estimation method. It also examines the possibility that economic sanctions are imposed in response to terrorist activities in sanctioned countries rather than the other way around. In order to better clarify the role of poverty and its link to economic sanctions and terrorism, this study introduces two-step regression models in which economic sanctions are first considered to be a cause of poverty and predicted poverty levels are then used to predict domestic terrorism; this test of robustness confirms that the imposition of economic sanctions does indeed lead to an increase in domestic terrorism. Overall, the findings of this study imply that although the intent of economic sanctions is to achieve certain policy goals, such as the promotion of humanitarianism, often they inadvertently result in the incitement of domestic terrorist activity within sanctioned countries.

\section{DEFINING TERRORISM AND ECONOMIC SANCTIONS}

Terrorism and economic sanctions are both contentious concepts that require clarification. This study follows LaFree and Dugan's (2007) definition of terrorism as an intentional act of violence, or threat of violence, by a non-state actor in order to attain a political, economic, religious, or social goal. Although the LaFree and Dugan definition is one of the most widely used definitions in the literature, it is not immune from criticism because it does not distinguish between threats and actual terrorist incidents. To justify the inclusion of threats 
of force, LaFree and Dugan $(2007,186)$ cite Bruce Hoffman's $(1998,38)$ contention that "terrorism is as much about the threat of violence as the violent act itself"; the relevance of this argument is obvious, e.g., in numerous aerial hijackings ("I have a bomb and I will use it unless you follow my demands"). The use of LaFree and Dugan's definition excludes state or state-sponsored terrorism from the empirical analysis used in this study. Accordingly, this study examines terrorism initiated only by sub-national actors. When perpetrators and targets are from the same country, an act of violence is defined as domestic terrorism; a well-known example in the United States is the Oklahoma City bombing of April 19, 1995 in which American-born Timothy McVeigh bombed the Alfred P. Murrah Federal Building in downtown Oklahoma City.

The term 'economic sanctions' is also subject to various definitional disputes, but this study utilizes the definition of Hufbauer et al. (2008), as it is their sanctions data which is used for empirical analysis in this study. Economic sanctions are defined as "the deliberate, government-inspired withdrawal, or threat of withdrawal, of customary trade or financial relations" between countries (2008, 3 - -although the empirical analysis below is confined to those cases of sanctions that are actually imposed on target countries. Shea $(2008,71)$ refines this definition to include coercive economic measures that "are deliberately implemented to deter, alter, or revise a state or group's political, military, or economic behavior that the sanctioner deems inappropriate." Examples of economic sanctions include trade embargoes, restrictions on imports and exports, the denial of foreign assistance (including loans and investments), the freezing of foreign assets, and the prohibition of economic transactions between multinational corporations and sanctioned countries. Not surprisingly, proponents of economic sanctions believe that their imposition forces rogue leaders to change their foreign policy behavior; the inducement, they believe, is the fear of seeing a decline in the functioning of their national economy, as well as the fear of experiencing isolation from the global economy (Einisman 2000).

\section{ECONOMIC SANCTIONS, POVERTY, AND DOMESTIC TERRORISM}

This section explains how, upon the imposition of economic sanctions, poor people are prone to experience abject poverty and then to turn terrorism in despair. Hufbauer et al. $(2008,105)$ find that "costs to target countries averaging merely 3 percent of GNP may seem small." Yet, when we think about this kind of a decrease extends over two or three years, this has the potential to put tremendous 
hardships on the poor. In fact, the poor often suffer the most acutely from economic losses caused by sanctions, however small the total loss may be. Accordingly, it is not difficult to imagine that the economic pain experienced by poor people would trigger terrorist violence, as was implied in the epigraph (Weiss et al. 1997).

Notwithstanding the proverb which tells us "poverty is not a sin," those actually living in poverty face social stigmas that facilitate isolation, humiliation, and mistrust. This is not to say that poor people turn to violence simply because of the consequences associated with stigmatization; instead, it is to argue that masses of poor may become violent when an additional external shock pushes these affects to the extreme. When the poor population of a sanctioned country believes that poverty is not their fault but is, rather, a result of their denial of economic opportunity by the rich and powerful, a vicious cycle of disempowerment, disenfranchisement, and despair cuts off their escape from the poverty that entraps them and their family members. This study believes that such circumstances create "a violence trigger structure," driving them to perceive their poverty as a form of social injustice; they may, consequently, turn to political violence in the effort to vent their frustration and avenge their abuse. This conceptualization is consistent with Krieger and Meierrieks's (2010, 4) assessment of the concept of "relative deprivation" originally put forward by Gurr (1970), namely, that "poor structural economic conditions create frustration, which in turn makes violence more likely."3

As supporters of economic sanctions put it, the use of economic sanctions inflicts economic suffering on the sanctioned population who are then supposed to put political pressure on their government to change its foreign policy (Nossal 1989; Hufbauer et al. 2008).4 Although this rationale may seem logical from the perspective of countries initiating sanctions, it is utterly ignorant of the suffering imposed upon a sanctioned population as economic conditions start to deteriorate. Once economic sanctions are put in place, the breakdown of economic func-

\footnotetext{
${ }^{3}$ However, the findings of Krueger and Maleckova (2003) and Dreher and Gassebner (2008) suggest that any connection between poverty and terrorism is indirect and weak.

${ }^{4}$ Another strand of the economic sanction literature deals with the question of whether economic sanctions increase government repression. For example, Wood (2008) and Peksen (2009) show that economic sanctions worsen government respect for human rights and are associated with increasing suppression of popular dissent (see also Piazza and Walsh 2010). Since the main purpose of this study is to examine the effect of economic sanctions, rather than government repression in the context of terrorism, the latter is not discussed. However, it is plausible that increased repression may lead to hopelessness and despair, thus creating more terrorism. Since this conjecture assumes that government repression is an intervening variable between economic sanctions and terrorism, it requires a different type of statistical modeling. For this reason, it is left for future research.
} 
tion can be expected to follow; however, economic hardship is not likely to be evenly distributed across domestic constituencies. Among the various social classes, the standard of living of the poor is likely to experience the greatest degradation due to the shortage of economic necessities, while that of the rich tends to be the least affected (Weiss et al. 1997; Weiss 1999; Wood 2008). Upon the imposition of economic sanctions, rulers in a sanctioned country must find other ways to compensate for the decrease in government revenue and foreign economic resources. This situation often forces rulers to redistribute what are now limited economic sources by continuing to pay off the rich and powerful-who are the main supporters of the incumbent regime - while cutting back on welfare support provided to the poor; given that their priority is to stay in power, such an unfair redistribution strategy should be no surprise even if it does mean pushing the poor over a cliff (Escribá-Folch and Wright 2010).

While the wealthy are able to enjoy relative abundance of economic resources even in an under-functioning national economy, sanctions will personally affect the poor who are subject to wage cuts, job loss, starvation, and epidemic diseases. Unemployed and financially-stricken people often perceive their absolute lack of upward social mobility no matter what kinds of effort they make (Niblock 2001); such a mindset undoubtedly breeds a sense of relative deprivation among the poor and, consequently, encourages the development of anger and resentment toward the rich and powerful (Gurr 1970). Put differently, economic sanctions work like "a violence trigger structure" in which the poor feel trapped in a cycle of poverty and are bound, then, to commit political violence in an effort to escape. A desperate economic situation often causes poor and disadvantaged segments of the population, who believe they have nothing to lose, to lash out against the government and its institutions, as well as against those members of society who are well-insulated from economic hardship; that is, the poor and disenfranchised are prone to become domestic terrorists due to their feelings of anger, frustration, and a perceived lack of alternatives. ${ }^{5}$ Several recent studies show that poor people do, in fact, turn to domestic terrorism out of feelings of relative economic deprivation (Wood 2008; Peksen 2009; Piazza 2011). Allen (2008), for instance,

\footnotetext{
${ }^{5}$ It is also worth noting that, in general, poor people make easy targets for recruitment by domestic terrorist groups. Terrorist groups often exploit the conditions of the poor by capitalizing on feelings of displeasure which they associate with a lack of access to basic needs such as clean water, nutrition, healthcare, education, clothing, and shelter. Feelings of deprivation, discrimination, and frustration are frequently aimed at a country's wealthier populations; these feelings are then manipulated by terrorist groups which recruit disgruntled individuals under the guise of facilitating social change. Members of impoverished populations may believe that by joining domestic terrorist groups, they have the opportunity to demand and realize social justice.
} 
finds that sanctions increase the level of violence against a government whenever the poor blame its institutions for their economic struggles. Similarly, Marinov (2005) shows that sanctions destabilize the targeted leadership of a country as a consequence of growing anti-government violence and pressure on the regime.

Washington Post columnist David Broder (1998) witnesses the economic misery of the poor, emphasizing: "if there is an economic impact on the targeted country, too often it is felt by its oppressed population, not the smug, well-insulated rulers." Similarly, in her New York Times article, "Economic Sanctions harm Iranian People, not Regime," Janessa Schilmoeller (2012) reports that a recent Gallup poll "highlights increased hardships among Iranians facing harsher international economic sanctions. In fact, $48 \%$ of Iranians reported instances over the past 12 months when they did not have enough money to buy food or pro-

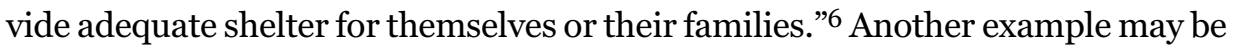
found in the case of the Smith regime in Rhodesia where the black communitywhich already was disproportionally the poorest segment of the population - was significantly more distressed than its white counterpart after the imposition of economic sanctions (Galtung 1967; Rowe 2001). This example further illustrates the argument that economic sanctions serve to deprive the poorest populations of their basic human rights to the means for survival. In this context, this study conceptualizes economic sanctions as "a violence trigger structure," hypothesizing that they are capable of inciting political violence among the poor, whose economic deprivation has become seemingly insurmountable due to additional burdens resulting from the imposition of sanctions. In other words, coercive economic sanctions damage the social safety net of the poor, thus intensifying their economic misery and generating poverty-related political violence. Therefore, the hypothesis that emerges from the above discussion is as follows:

H1: When economic sanctions are imposed, the likelihood of domestic terrorism increases.

\section{RESEARCH DESIGN}

To test the domestic terrorism hypotheses, this study collects a sample of 152

\footnotetext{
${ }^{6}$ Another New York Times article notes that as a result of the sweeping economic sanctions imposed on Haiti by the United Nations, "for people at the bottom of the ladder ... the battle has become one of day-to-day survival. Mrs. Pierre, 25, said she had not eaten in 36 hours and was reduced to 'asking people for whatever they can afford to give' for herself and her two small sons" (Larry Rohter 1994).
} 
countries during the period from 1970 to 2004; thus, its unit of analysis is the country year. ${ }^{7}$ The study period is chosen given that the terrorism dataset is available only after 1970 (LaFree and Dugan 2007; Enders, Sandler, and Gaibulloev 2011) and the economic sanctions data ends in 2004 (Hufbauer et al. 2008).

The dependent variable, domestic terrorism, is a count measure and represents the total number of domestic terrorist incidents occurring in a country per year. The data comes from the worldwide terrorism dataset of Enders, Sandler and Gaibulloev (2011), who systematically separated LaFree and Dugan's (2007) Global Terrorism Database (GTD) 8 into domestic and international terrorist incidents. Enders, Sandler and Gaibulloev underscore that "no other article provides such a complete partitioning of domestic and transnational incidents" $(2011,3)$.

The main independent variable, economic sanctions, is based on Hufbauer et al.'s (2008) data collection, which is considered to be the most comprehensive and sophisticated available in regard to economic sanction cases'; it is then supplemented with other sources including Drezner (1999) and O'Sullivan (2003). The economic sanctions variable is coded as ' 1 ' for the imposition of economic sanctions and as 'o' for the lack of sanctions. This study creates three additional sanctions variables by identifying economic sanctions imposed by the United States, unilateral sanctions, and multilateral sanctions, respectively. Because the empirical results for these sanctions are similar to those for economic sanctions (i.e., the dichotomous measure of all sanctions events), they are not reported below in order to save space.

To ensure that the estimated results are not subject to omitted variable bias, and thus flawed, this study includes six control variables: democracy, state failure, economic development, population, post-Cold War, and a lagged term for the dependent variable. These six variables, which are elaborated below, were chosen because previous studies provide evidence of their influence on terrorist activity. ${ }^{10}$ The GTD's broad definition of terrorism also includes attacks occurring dur-

\footnotetext{
${ }^{7}$ Dyadic analysis is not useful because no reciprocity is expected between sanctioners and domestic terrorists, i.e., terrorist targets are not sanctioning countries.

${ }^{8}$ For more detailed information on GTD, accessed at www.start.umd.edu/gtd/.

${ }^{9}$ When the Threat and Imposition of Sanctions (TIES) data is used instead, the results are similar to those reported below so that they are not reported here to save space. The TIES data can be accessed at www.unc.edu/ bapat/TIES.htm.

${ }^{10}$ The discussion of the six control variables is presented in the context that they are likely to affect international as well as domestic terrorism for similar reasons. For example, Savun and Phillips $(2009,879)$ make a similar note of the fact that "if democracies are prone to transnational terrorism by design, as most existing theoretical arguments suggest, then democracies should be vulnerable to domestic terrorism as well." Young and Findley (forthcoming, 15 and 22) also point out that "Li's arguments [on the relationship between democracy and transnational terrorism] may be accurate when we apply his reasoning to domestic terrorism as opposed to the transnational form."
} 
ing civil wars and low-level insurgencies - instance, violence by UNITA in Angola and the PKK in Turkey is included in the database; because the terrorism measure already reflects the presence of civil war, this study does not include civil war as an independent variable. ${ }^{11}$

Some studies show that democracy is inversely proportional to terrorism because it provides peaceful channels for conflict resolution (Schmid 1992; Eyerman 1998; Li 2005); other studies argue the contrary, reporting that democracy allows for greater terrorist activity due to its commitment to individual freedoms (Eubank and Weinberg 1994, 2001). Despite these discrepancies, this study adopts the perspective that there exists a positive correlation between terrorism and democracy: the high level of civil liberties present in a democracy helps to facilitate the planning of terrorist events, thus making them more vulnerable to terrorist attacks. The democracy variable is taken from the Polity dataset which provides an eleven point additive score for both democracies and autocracies in order to capture the overall quality of democratic political institutions. Each additive score ranges from o to 10. Subtracting the autocracy score from the democracy score gives a composite democracy score ranging from full democracy $(+10)$ to full autocracy (-10) (Marshall and Jaggers 2007).

Previous studies have provided empirical support for the positive relationship between failed states and terrorism (LaFree, Dugan, and Fahey 2007; Piazza 2008). Because the political leadership of a failed state is too weak to exercise legal authority over much of its territory, a variety of terrorist activities have the opportunity to develop. For example, it is now feared that Sudan is a sanctuary for terrorists, not only because its political community has vanished in the absence of fair political and judicial systems, but also because a large segment of its public feels disenfranchised and marginalized (Rotberg 2002). The failed state variable ranges from $o$ to 17 by combining the severity of ethnic wars (o-4), revolutionary wars (0-4), adverse regime changes (0-4), and genocides and politicides (0-5); this data comes from the Political Instability Task Force (2007).

Several recent studies show that wealthy countries are more likely to experience terrorism because they are symbols of the political and economic status quo and because they provide more potential terrorist targets than do less developed countries (Piazza 2011). Economic success attracts more terrorist attacks because economic inequality is usually assessed globally in the form of poor versus rich countries (Krieger and Meierrieks 2010; for a dissenting view, see Krueger 2007). The main argument for economic development revolves around the notion of

${ }^{11}$ When included, the robustness of the economic sanctions variable remains. 
poor versus rich countries rather than around the concept of poor versus rich people within each country; it is the latter case which provides a basis for the conceptualization of this study on economic sanctions. The economic development variable is measured by the logged real GDP per capita, adjusted for purchasing power parity. Data for this variable was obtained from Gleditsch (2002) and has been updated with base data from the new 6.3 version of the Penn World Tables (Heston, Summers, and Aten 2009).

Highly populated countries naturally have greater difficulty providing an adequate level of security and have, thus, a higher risk of experiencing terrorist plots and attacks (Eyerman 1998). Savun and Phillips (2009) have found evidence that highly populated countries experience more terrorist incidents than their smaller counterparts. With this in mind, the population variable, as measured by the logged total population, is projected to produce an increase in terrorism due to the relative difficulty of successfully policing a larger population. Data for this variable is taken from the U.S. Census Bureau (2008).

Enders and Sandler (2006) provide evidence to the effect that the total number of terrorist attacks has decreased since the end of Soviet funding of left-wing groups. In order to spread their political ideology, during the Cold-War period, left-wing groups often relied on terrorist attacks. However, the justification for continuing to carry out such terrorist missions has drastically diminished with the end of the ideological struggles coinciding with the demise of the former Soviet Union (Fukuyama 1992). To account for the systematic decrease in terrorist activity which took place after the end of the Cold War, a post-Cold War variable is included. The post-Cold War variable is coded as ' 1 ' since 1991 and as 'o' otherwise.

This study also controls for a country's past history of terrorism by adding a lagged dependent variable on the right-hand side of the equation. The lagged dependent variable has the potential to "soak up" the explanatory power of theoretically interesting independent variables (Achen 2000); however, it is theoretically appropriate that, as previous research demonstrates, countries with past incidents of domestic terrorism are likely to be more vulnerable to terrorism in the present or in the future (Savun and Phillips 2009; Young and Findlely forthcoming).

Because the dependent variable is operationalized as the total number of terrorist events per year, this study employs a negative binomial maximum-likelihood regression model with Huber-White robust standard errors, clustered by country. This estimation method is chosen over Poisson regression, as the variance of the terrorism data is much larger than its mean. Negative binomial regression adds a dispersion parameter to model the unobserved heterogeneity among 
observations, allowing the variance to exceed the mean; this essentially corrects for the over-dispersion found in Poisson regression models (Long and Freese 2006; Hilbe 2007). All predictors are lagged one year behind the outcome variable to ensure that the former cause the latter, rather than the other way around.

\section{EMPIRICAL RESULTS}

This section discusses the statistical significance of estimated coefficients, presents an analysis of their substantive effects, and offers two sets of two-step analyses of reverse causality, as well as of economic sanctions, poverty and domestic terrorism. Table 1 includes three models that display empirical results relating economic sanctions to the occurrence of terrorism. Model 1 presents negative binomial regression estimates. As hypothesized, the economic sanctions variable is statistically significant at the 0.001 level and is in the expected direction; when countries have economic sanctions imposed on them, they are likely to experience more domestic terrorist incidents. For example, Iran experienced an increase of $145 \%$ in domestic terrorism during the periods of economic sanctions between 1979-1981 and 1984-2002. This evidence supports the hypothesis that because poor people cannot break out of the spiral of poverty embedded in "a violence trigger structure" created by the imposition of economic sanctions, their natural reaction is to lash out against the rich and the government. In short, it appears that the despair of poor populations often leads them to participate in domestic terrorism as a means of revolt against the social injustice they view as the cause of their poverty. All of the control variables - with the exception of post-Cold War-achieve significance. Democracy is positively associated with domestic terrorism; failed states suffer from more domestic terrorist incidents; developed countries experience more domestic terrorism; highly populated countries are more likely to be plagued with domestic terrorism; and countries with a terrorist history are, naturally, more vulnerable to its recurrence.

Model 1 relies on negative binomial regression under the assumption that all countries should, in principle, be equally as vulnerable to terrorist activity; however, because relatively few countries are actually victims of terrorism, it is highly probable that an excess of non-events might occur in the distribution of the dependent variable. In this case, a standard negative binomial regression estimation method loses some of its effectiveness, both statistically and logically, because the prevalence of zero counts in the data can pose a challenge if not estimated appropriately. Zero-inflated negative binomial regression is one of the widely used estimators designed to address the issue of excessive zeros. 
Table 1. The Effect of Economic Sanctions on Domestic Terrorism

\begin{tabular}{|c|c|c|c|}
\hline Variable & $\begin{array}{c}\text { Negative Binomial } \\
\text { Model } 1\end{array}$ & $\begin{array}{l}\text { Zero-Inflated NB } \\
\text { Model } 2\end{array}$ & $\begin{array}{l}\text { Conditional Fixed-Effects } \\
\text { Model } 3\end{array}$ \\
\hline Economic Sanctionst-1 & $\begin{array}{l}0.910^{* * *} \\
(0.216)\end{array}$ & $\begin{array}{l}0.571^{* * *} \\
(0.152)\end{array}$ & $\begin{array}{l}0.244^{* * *} \\
(0.067)\end{array}$ \\
\hline Democracyt-1 & $\begin{array}{l}0.050^{\star * *} \\
(0.012)\end{array}$ & $\begin{array}{c}0.019 \\
(0.013)\end{array}$ & $\begin{array}{l}0.044^{* * *} \\
(0.005)\end{array}$ \\
\hline State Failuret-1 & $\begin{array}{l}0.251^{* * *} \\
(0.047)\end{array}$ & $\begin{array}{l}0.146^{* * *} \\
(0.043)\end{array}$ & $\begin{array}{l}0.138^{* * *} \\
(0.012)\end{array}$ \\
\hline Economic Developmentt-1 & $\begin{array}{l}0.198^{*} \\
(0.093)\end{array}$ & $\begin{array}{c}0.123 \\
(0.095)\end{array}$ & $\begin{array}{l}0.300^{* * *} \\
(0.037)\end{array}$ \\
\hline Populationt-1 & $\begin{array}{l}0.462^{* * *} \\
(0.062)\end{array}$ & $\begin{array}{l}0.337^{* * *} \\
(0.056)\end{array}$ & $\begin{array}{l}0.135^{* * *} \\
(0.025)\end{array}$ \\
\hline Post-Cold Wart-1 & $\begin{array}{c}0.176 \\
(0.129)\end{array}$ & $\begin{array}{l}-0.242^{*} \\
(0.109)\end{array}$ & $\begin{array}{c}0.048 \\
(0.052)\end{array}$ \\
\hline Terrorismt-1 & $\begin{array}{l}0.033^{* * *} \\
(0.006)\end{array}$ & $\begin{array}{l}0.021^{* * *} \\
(0.003)\end{array}$ & $\begin{array}{l}0.005^{\star * *} \\
(0.000)\end{array}$ \\
\hline Constant & $\begin{array}{c}-5.835^{\star \star \star} \\
(0.956)\end{array}$ & $\begin{array}{l}-2.845^{* * *} \\
(0.863)\end{array}$ & $\begin{array}{c}-5.341^{* * *} \\
(0.399)\end{array}$ \\
\hline Economic Sanctiont-1 & & $\begin{array}{l}-0.295 \\
(0.221)\end{array}$ & \\
\hline Democracyt-1 & & $\begin{array}{c}-0.043^{* * *} \\
(0.013)\end{array}$ & \\
\hline State Failuret-1 & & $\begin{array}{l}-0.171^{* * *} \\
(0.050)\end{array}$ & \\
\hline Economic Developmentt-1 & & $\begin{array}{l}-0.112 \\
(0.095)\end{array}$ & \\
\hline Populationt-1 & & $\begin{array}{l}-0.179^{* *} \\
(0.060)\end{array}$ & \\
\hline Post-Cold Wart-1 & & $\begin{array}{l}-0.673^{* * *} \\
(0.167)\end{array}$ & \\
\hline Terrorismt-1 & & $\begin{array}{l}-1.533^{* * *} \\
(0.308)\end{array}$ & \\
\hline Constant & & $\begin{array}{c}3.818^{* * *} \\
(0.962)\end{array}$ & \\
\hline Wald $\mathrm{Chi}^{2}$ & 415.78 & 330.67 & 850.48 \\
\hline Prob $>\mathrm{Chi}^{2}$ & 0.001 & 0.001 & 0.001 \\
\hline Log Pseudolikelihood & -7885.34 & -7461.29 & \\
\hline Log Likelihood & & & -6648.73 \\
\hline Dispersion $=1$ & 4.25 & 1.94 & \\
\hline Observations & 4,367 & 4,367 & 4,215 \\
\hline Nonzero Observations & & 1,667 & \\
\hline Zero Observations & & 2,700 & \\
\hline
\end{tabular}

Note: ${ }^{*} p<.05,{ }^{* *} p<.01,{ }^{* * *} p<.001$, one-tailed tests. 
Therefore, Model 2 reports zero-inflated negative binomial regression estimates in two parts: the Not Always-o group (i.e., a terrorism-prone country), which might have a zero terrorist count as well as a nonzero probability that it has a positive count, and the Always-o group (i.e., a terrorism-free country), which has an outcome of $\mathrm{O}$ with a probability of $1 .{ }^{12}$ Although the presence of excessive zeros in the domestic terrorism data is considered in Model 2, the economic sanctions variable still exerts the primary exacerbating effect on domestic terrorism. Model 3 takes into account Green, Kim and Yoon's $(2001,442)$ criticism that "analyses of [cross-sectional, time-series] data that make no allowance for fixed unobserved differences between [countries] often produce biased results." The conditional fixed-effects negative binomial regression estimator in Model 3 does not cause economic sanctions to become insignificant, as its coefficient remains significantly different from zero. Again, economic sanctions are positively associated with domestic terrorism.

In addition to their statistical significance, it is important to estimate the substantive effects of the variables of interest. If substantive effects are consistent with statistical significance, then the estimated results reported so far can be considered meaningful. As an example, this study looks at the substantive effect of the economic sanctions variable in Model 1 of Table 1 . It turns out that the substantive effect is consistent with the statistically significant effect. When the substantive effect of the economic sanctions variable (the coefficient of which is o.910) reported in Model 1 of Table 1 is calculated, this study finds evidence that countries under economic sanctions are likely to experience more meaningful and influential domestic terrorist incidents than are non-sanctioned countries. Upon the imposition of economic sanctions, the likelihood of domestic terrorism increases by $149 \%$.

This study has developed a plausible rationale as to why economic sanctions can be expected to increase the likelihood of domestic terrorism; it has also provided systematic empirical evidence in support of the theoretical expectation. Yet, the possibility remains that a complex reciprocal relationship exists between our variables of interest, with the imposition of sanctions and the incidence of domestic terrorism reinforcing one another; in other words, economic sanctions may be endogenous to terrorist activity in the sanctioned country. Although it is projected that sanctions provoke terrorist attacks, it may also be the case that the pres-

\footnotetext{
12 The Vuong (1989) test may be used to make a statistical choice between negative binomial regression and zero-inflated negative binomial regression (Green 2003; Long and Freese 2006; Hilbe 2007). However, because this study estimates robust standard errors, the Vuong test cannot be applied. When Vuong tests are performed without the robust option, zero-inflated negative binomial regression is preferred to negative binomial regression.
} 
ence of terrorist activity in a sanctioned country may induce additional economic sanctions. In fact, some existing studies have contended that terrorism is one reason why economic sanctions are imposed on terrorism-prone countries (Hufbauer et al. 2001).

The best way to account for this endogeneity bias is to build simultaneous equations models. However, standard simultaneous equations models are designed based on the assumption that two endogenous variables are continuous measures. Keshk's (2003) two-stage probit least squares model offers some advantages over standard simultaneous equations models because its endogenous variables may also be dichotomous and continuous measures. Keshk, Reuveny, and Pollins (2010) and Hegre, Oneal, and Russett (2010) rely on Keshk's simultaneous equations model. Unfortunately, because the endogenous variables in this study are a count measure (i.e., terrorism) and a dichotomous measure (i.e., economic sanctions), use of those simultaneous equations models will yield biased estimates. For this reason, after consulting Russett, Oneal and Davis (1998) and Choi and James (2004), this study utilizes two steps in the model building process. Step one evaluates the impact of five factors on economic sanctions, namely, terrorism, democracy, trade, economic growth, and a lagged term of economic sanctions. This step produces predicted values for economic sanctions that will be used in the second step. Step two, then, incorporates a one year-lagged term of the predicted values for economic sanctions - which was produced in step one-plus the same six predictors employed in the models in Table 1 (i.e., democracy, state failure, economic development, population, post-Cold War, and a lagged term for terrorism).

To be specific, the predicted values for economic sanctions from the first step are estimated by taking into account terrorism, democracy, trade, economic growth, and a lagged term for economic sanctions, all at time $t-1$; these five lagged independent variables are chosen so that there is a high level of confidence that they serve as a cause of the dependent variable rather than vice versa. The independent variables, namely, economic sanctions, terrorism, democracy, and a lagged term of economic sanctions, were fully discussed in the previous section, therefore this section is limited to an explanation of the trade and economic growth variables. When the economy of a target country is heavily dependent upon trade, economic sanctions are less likely to be imposed because they could potentially have very little impact on the target country while disrupting the world economy as a whole. ${ }^{13}$ More importantly, these trade dependent countries are

\footnotetext{
13 This is because the target countries can, often, easily find alternative suppliers of goods and services (Elliott 1998).
} 
unlikely to be sanctioned because almost all of them are liberal economies; liberal economies tend to impose coercive sanctions rather than be imposed upon. Countries with a high economic growth rate are unlikely to be under economic sanctions because they maintain a stable economic relationship with other countries as they pursue economic prosperity (O'Sullivan 2003; Fandl 2004).

To estimate in step one the economic sanctions model with a dichotomous dependent variable, this study uses logit regression with Huber-White robust standard errors, clustered by country. ${ }^{14}$ To estimate the terrorism model in step two, a negative binomial regression model is employed. To account for a possible endogeneity bias, the predicted values of economic sanctions are used for estimation, instead of the original economic sanctions values.

Table 2 reports the results for this two-step model building. The top part reports the estimated coefficients and standard errors from the economic sanctions equation in step one, while the bottom part displays the terrorism equation estimates from step two. Model 1 shows results for the effect of economic sanctions on domestic terrorism. It turns out that even when endogeneity bias is taken into consideration, the detrimental effect of economic sanctions remains (see the shaded row); economic sanctions again emerge as a cause of domestic terrorism. It is worth noting that the domestic terrorism variable turns out to be insignificant at step one, implying that domestic terrorist activities in sanctioned countries do not necessarily induce additional economic sanctions. This is, perhaps, because domestic terrorism is unlikely to directly affect the welfare of international powers.

Table 2. Two-Step Analysis of Economic Sanctions and Domestic Terrorism

\begin{tabular}{l|c}
\multicolumn{1}{c|}{ Variable } & $\begin{array}{c}\text { Negative Binomial Regression } \\
\text { Model 1 }\end{array}$ \\
\hline First Step: Economic Sanctionst & \\
\hline \multirow{2}{*}{ Terrorismt-1 } & 0.003 \\
& $(0.003)$ \\
\hline \multirow{2}{*}{ Democracyt-1 } & $-0.049^{\star \star *}$ \\
& $(0.015)$ \\
\hline \multirow{2}{*}{ Tradet-1 } & $-0.009^{* \star}$ \\
& $(0.003)$ \\
\hline \multirow{2}{*}{ Economic Growtht-1 } & -0.003 \\
& $(0.015)$ \\
\hline
\end{tabular}

${ }^{14}$ This study also implements a peace-years correction (a.k.a., logit splines) to take into consideration temporal dependence in the sanction data (Beck, Katz, and Tucker 1998). Since the results do not significantly deviate from those in Table 2 , they are not reported in order to save space. 


\begin{tabular}{|c|c|}
\hline Variable & $\begin{array}{c}\text { Negative Binomial Regression } \\
\text { Model } 1\end{array}$ \\
\hline Economic Sanctionst-1 & $\begin{array}{l}6.089^{* * *} \\
(0.285)\end{array}$ \\
\hline Constant & $\begin{array}{c}-3.639^{* * *} \\
(0.306)\end{array}$ \\
\hline Wald $\mathrm{Chi}^{2}$ & 599.65 \\
\hline Prob $>\mathrm{Chi}^{2}$ & 0.001 \\
\hline Log Pseudolikelihood & -407.62 \\
\hline Pseudo $\mathrm{R}^{2}$ & 0.70 \\
\hline Observations & 3,661 \\
\hline \multicolumn{2}{|c|}{ Second Step: Domestic Terrorismt } \\
\hline Predicted Economic Sanctiont-1 & $\begin{array}{c}1.073^{* * *} \\
(0.199)\end{array}$ \\
\hline Democracyt-1 & $\begin{array}{l}0.042^{\star * *} \\
(0.013)\end{array}$ \\
\hline State Failuret-1 & $\begin{array}{l}0.331^{* * *} \\
(0.060)\end{array}$ \\
\hline Economic Developmentt-1 & $\begin{array}{l}0.266^{* *} \\
(0.104) \\
\end{array}$ \\
\hline Populationt-1 & $\begin{array}{c}0.437^{\star \star *} \\
(0.065) \\
\end{array}$ \\
\hline Post-Cold Wart-1 & $\begin{array}{c}0.021 \\
(0.136) \\
\end{array}$ \\
\hline Terrorismt-1 & $\begin{array}{l}0.027^{* \star *} \\
(0.005)\end{array}$ \\
\hline Constant & $\begin{array}{l}-5.988^{* * *} \\
(1.010)\end{array}$ \\
\hline Wald $\mathrm{Chi}^{2}$ & 379.07 \\
\hline Prob $>\mathrm{Chi}^{2}$ & 0.001 \\
\hline Log Pseudolikelihood & -6917.70 \\
\hline Dispersion $=1$ & 3.94 \\
\hline Observations & 3,513 \\
\hline
\end{tabular}

Note: ${ }^{*} p<.05,{ }^{* *} p<.01,{ }^{* \star *} p<.001$, one-tailed tests.

The use of a two-step statistical analysis may become more clear when we interpret the theoretical arguments put forward in this study in the context of twostage progression to terrorist behavior (i.e., from sanctions to poverty and then from poverty to increased terrorism). Put differently, a two-step approach may help to clarify the role of poverty as a mediator between economic sanctions and 
domestic terrorism. By modeling poverty as a function of sanctions, democracy, and economic development, the first step examines whether the imposition of economic sanctions is linked to an increase of poverty. This study operationalizes poverty in two ways: 1) a poverty headcount ratio at $\$ 5$ a day and 2) the Gini index. The first measure comes from the World Bank's data collection on poverty 15 and it is the percentage of the population living on less than $\$ 5.00$ a day ${ }^{16}$ at 2005 international prices. The second measure is the Gini index which measures net income inequality within each country, ranging from o to 100. As economic sanctions are more likely to degrade the economic well-being of the poor than of the rich, we should expect to see a widening of the income distribution gap. Data is collected from Solt's (2009) Standardized World Income Inequality Database. Measurements for democracy and economic development are the same as before. The first step is the generation of predicted values for poverty (measures by either poverty headcount ratio or Gini index), which will serve as the main predictors of terrorism at step two. The second step, then, incorporates a one year-lagged term of the predicted values for poverty, along with the same control variables that appeared in the previous models. Step two is designed to explore, while controlling for other causal factors, whether or not poverty provokes terrorist incidents.

Table 3 presents estimated results using OLS regression at the first step and negative binomial regression at the second step. It should be noted that due to the lack of poverty data available for numerous countries and for numerous years, much fewer observations are used in this estimation. ${ }^{17}$ Nonetheless, the top parts of Models 1 and 3 test the domestic terrorism hypothesis. When step one regresses poverty headcount ratio and income inequality (in Models 1 and 3, respectively) against economic sanctions, it produces results in which the sanctions variable is statistically significant at the 0.001 level and in the hypothesized direction. This result provides additional support for the argument that the poor suffer disproportionately from the effects of economic sanctions.

The question remains, though, whether an increased level of poverty indeed contributes to an increase in domestic terrorism. Step two in Models 1 and 3 is designed to answer this question by regressing terrorism on a one-year lagged term of the predicted values for either poverty headcount ratio or income inequality along with the six control variables. As expected, the predicted variable

\footnotetext{
${ }^{15}$ Accessed at http://data.worldbank.org/topic/poverty.

${ }^{16}$ Use of $\$ 1.25, \$ 2.00, \$ 2.50$ or $\$ 4.00$ a day yields virtually similar results.

${ }^{17}$ This smaller coverage of poverty data may appear to reduce comparability across countries over a longer time period. The limited data for poverty is the main reason the two-step tests are not put forward as the main empirical analysis of this study.
} 
achieves significance with a positive sign indicating that as the level of either poverty headcount ratio or income distribution increases, the risk of terrorism increases as well. In an attempt to avoid the potential bias stemming from omitted variables, Models 2 and 4 modify the model from step one by adding two additional factors associated with poverty; at the same time, they maintain the same model specification at step two. Even with this modification, the economic sanctions variable at step one turns out to be statistically significant and in the hypothesized direction; furthermore, the poverty predicted variable at step two remains significant with a positive sign. Again, these findings corroborate the hypothesis that economic sanctions are a causal factor in the emergence of terrorism.

Table 3. Two-Step Analysis of Economic Sanctions, Poverty, and Domestic Terrorism

\begin{tabular}{|c|c|c|c|c|}
\hline \multirow{3}{*}{ Variable } & \multicolumn{4}{|c|}{ Negative Binomial Regression } \\
\hline & \multicolumn{2}{|c|}{ Poverty Headcount Ratio } & \multicolumn{2}{|c|}{ Gini Coefficient } \\
\hline & Model 1 & Model 2 & Model 3 & Model 4 \\
\hline \multicolumn{5}{|l|}{ First Step: Poverty } \\
\hline Economic Sanctionst-1 & $\begin{array}{c}6.438^{* * *} \\
(2.043)\end{array}$ & $\begin{array}{l}2.443^{*} \\
(1.237)\end{array}$ & $\begin{array}{c}6.611^{* * *} \\
(0.573)\end{array}$ & $\begin{array}{c}4.600^{* * *} \\
(0.523)\end{array}$ \\
\hline Democracyt-1 & & $\begin{array}{c}-0.520^{* * *} \\
(0.080)\end{array}$ & & $\begin{array}{l}0.075^{\star *} \\
(0.030)\end{array}$ \\
\hline Economic Developmentt-1 & & $\begin{array}{c}-24.831^{* * *} \\
(0.600)\end{array}$ & & $\begin{array}{c}-4.613^{* * *} \\
(0.205)\end{array}$ \\
\hline Constant & $\begin{array}{c}69.746^{\star \star *} \\
(0.836)\end{array}$ & $\begin{array}{c}275.755^{\star * *} \\
(4.891)\end{array}$ & $\begin{array}{c}38.162^{* * *} \\
(0.210)\end{array}$ & $\begin{array}{c}78.084^{* * *} \\
(1.740)\end{array}$ \\
\hline F-Statistic & 9.93 & 767.00 & 133.27 & 274.39 \\
\hline Prob > F-Statistic & 0.002 & 0.001 & 0.001 & 0.001 \\
\hline Observations & 1,291 & 1,291 & 2,762 & 2,762 \\
\hline \multicolumn{5}{|c|}{ Second Step: Domestic Terrorismt } \\
\hline Predicted Povertyt-1 & $\begin{array}{l}0.076^{* *} \\
(0.032)\end{array}$ & $\begin{array}{l}0.070^{*} \\
(0.039)\end{array}$ & $\begin{array}{c}0.137^{* * *} \\
(0.032)\end{array}$ & $\begin{array}{c}0.186^{* * *} \\
(0.045)\end{array}$ \\
\hline Democracyt-1 & $\begin{array}{l}0.042^{\star *} \\
(0.016)\end{array}$ & $\begin{array}{l}0.076^{\star * *} \\
(0.022)\end{array}$ & $\begin{array}{l}0.037^{* *} \\
(0.016)\end{array}$ & $\begin{array}{c}0.023 \\
(0.017)\end{array}$ \\
\hline State Failuret-1 & $\begin{array}{l}0.574^{\star * *} \\
(0.099)\end{array}$ & $\begin{array}{c}0.593^{* * *} \\
(0.098)\end{array}$ & $\begin{array}{l}0.394^{* * *} \\
(0.077)\end{array}$ & $\begin{array}{c}0.394^{\star * *} \\
(0.076)\end{array}$ \\
\hline Economic Developmentt-1 & $\begin{array}{l}0.313^{*} \\
(0.152)\end{array}$ & $\begin{array}{l}2.040^{*} \\
(1.019)\end{array}$ & $\begin{array}{l}0.213^{*} \\
(0.118)\end{array}$ & $\begin{array}{l}1.060^{* * *} \\
(0.253)\end{array}$ \\
\hline Populationt-1 & $\begin{array}{c}0.462^{* * *} \\
(0.085)\end{array}$ & $\begin{array}{l}0.474^{\star \star *} \\
(0.084)\end{array}$ & $\begin{array}{c}0.485^{\star * \star} \\
(0.072)\end{array}$ & $\begin{array}{l}0.483^{* * *} \\
(0.072)\end{array}$ \\
\hline Post-Cold Wart-1 & $\begin{array}{l}-0.185 \\
(0.203)\end{array}$ & $\begin{array}{l}-0.167 \\
(0.200)\end{array}$ & $\begin{array}{c}0.019 \\
(0.129)\end{array}$ & $\begin{array}{c}0.012 \\
(0.128)\end{array}$ \\
\hline
\end{tabular}




\begin{tabular}{|c|c|c|c|c|}
\hline \multirow{3}{*}{ Variable } & \multicolumn{4}{|c|}{ Negative Binomial Regression } \\
\hline & \multicolumn{2}{|c|}{ Poverty Headcount Ratio } & \multicolumn{2}{|c|}{ Gini Coefficient } \\
\hline & Model 1 & Model 2 & Model 3 & Model 4 \\
\hline Terrorismt-1 & $\begin{array}{c}0.014^{* * *} \\
(0.004)\end{array}$ & $\begin{array}{c}0.015^{\star * *} \\
(0.004)\end{array}$ & $\begin{array}{c}0.025^{\star * *} \\
(0.005)\end{array}$ & $\begin{array}{c}0.026^{* * *} \\
(0.005)\end{array}$ \\
\hline Constant & $\begin{array}{c}-11.710^{* * *} \\
(2.757)\end{array}$ & $\begin{array}{l}-25.695^{*} \\
(11.221)\end{array}$ & $\begin{array}{c}-11.295^{\star * *} \\
(1.651)\end{array}$ & $\begin{array}{c}-20.478^{* * *} \\
(3.732)\end{array}$ \\
\hline Wald $\mathrm{Chi}^{2}$ & 276.76 & 279.26 & 247.45 & 253.91 \\
\hline Prob $>\mathrm{Chi}^{2}$ & 0.001 & 0.001 & 0.001 & 0.001 \\
\hline Log Pseudolikelihood & -2749.11 & -2752.01 & -5777.69 & -7885.34 \\
\hline Dispersion $=1$ & 3.00 & 3.02 & 3.45 & 3.47 \\
\hline Observations & 1,194 & 1,194 & 2,608 & 2,608 \\
\hline
\end{tabular}

Note: ${ }^{*} p<.05,{ }^{* *} p<.01,{ }^{* *} p<.001$, one-tailed tests.

\section{CONCLUSION}

This study sheds new light on the role of poverty in the context of economic sanctions and domestic terrorism. The data analysis indicates that when economic sanctions are imposed, they are likely to exacerbate the anger of impoverished populations, the members of which are then more likely to turn to terrorism. This study believes that although sanctions are intended to apply pressure to political leaders in rogue governments, the economic misery they disproportionately inflict upon the poorest citizens of a country often intensifies their feelings of bitterness and despair; they are, then, more likely to seek revenge through terrorism, thereby producing an unanticipated additional effect of economic sanctions. On balance, it seems that economic sanctions do more harm than good insofar as they encourage additional terrorist incidents. Accordingly, foreign policy decision makers should think twice before implementing economic sanctions aimed at achieving certain policy goals such as humanitarianism; at the very least they should seek ways of minimizing the unintended adverse side effects sanctions impose on the most vulnerable segments of society within sanctioned countries.

\section{REFERENCES}

Achen, Christopher. 2000. "Why Lagged Dependent Variables Can Suppress the Explanatory Power of other Independent Variables.” Working paper, 
Society for Political Methodology, St. Louis, WA.

Allen, Susan Hannah. 2008. "The Domestic Political Costs of Economic Sanctions." Journal of Conflict Resolution 52(6), 916-944.

Beck, Nathaniel, Jonathan Katz and Richard Tucker. 1998. "Taking Time

Seriously." American Journal of Political Science 42(4), 1260-1288.

Broder, David. S. 1998. "Sanctions Addicts." Washington Post (June 24), A17.

Choi, Seung-Whan and Patrick James. 2004. "Civil-Military Relations in a Neo-

Kantian World, 1886-1992.” Armed Forces \& Society 3o(2), 227-254.

Dreher, Axel and Martin Gassebner. 2008. "Does Proximity to the United States Cause Terror?” Economics Letters 99(1), 27-29.

Drezner, Daniel. 1999. The Sanctions Paradox: Economic Statecraft and International Relations. New York: Cambridge University Press.

Einisman, Alan. 2000. "Ineffectiveness at Its Best: Fighting Terrorism with Economic Sanctions." 9 Minnesota Journal of Global Trade 299.

Elliott, Kimberley Ann. 1998. "The Sanctions Glass: Half Full or Completely Empty?" International Security 23(1), 50-65.

Enders, Walter and Todd Sandler. 2006. The Political Economy of Terrorism. Cambridge and New York, NY: Cambridge University Press.

Enders, Walter, Todd Sandler and Khusrav Gaibulloev. 2011. "Domestic versus Transnational Terrorism: Data, Decomposition, and Dynamics." Journal of Peace Research 48(3), forthcoming.

Escribá-Folch, Abel and Joseph Wright. 2010. "Dealing with Tyranny: International Sanctions and the Survival of Authoritarian Rulers." International Studies Quarterly 54(2), 335-359.

Eubank, William and Leonard Weinberg. 1994. "Does Democracy Encourage Terrorism?" Terrorism and Political Violence 6(4), 417-443. . 2001. "Terrorism and Democracy: Perpetrators and Victims." Terrorism and Political Violence 13(1), 155-164.

Eyerman, Joe. 1998. "Terrorism and Democratic States: Soft Targets or Accessible Systems." International Interactions 24(2), 151-170.

Fandl, Kevin J. 2004. "Terrorism, Development \& Trade: Winning the War on Terror without the War." 19 American University International Law Review 587.

Fukuyama, Francis. 1992. The End of History and the Last Man. New York: Free Press.

Galtung, Johan. 1967. "On the Effects of International Economic Sanctions: With Examples from the Case of Rhodesia." World Politics 19(3), 378-416.

Gleditsch, Kristian. 2002. "Expanded Trade and GDP Data." Journal of Conflict Resolution 46(5), 712-724. Accessed at http://privatewww.essex.ac.uk/ 
$\sim \mathrm{ksg} /$ exptradegdp.html.

Green, Donald P., Soo Yeon Kim and David H. Yoon. 2001. "Dirty Pool." International Organization 55(2), 441-468.

Gurr, Ted Robert. 1970. Why Men Rebel. Princeton, NJ: Princeton University Press.

Halperin, Morton, Joe Siegle and Michael Weistein. 2005. The Democracy Advantage: How Democracies Promote Prosperity and Peace. New York: Routledge.

Hegre, Havard, John R. Oneal and Bruce Russett. 2010. "Trade Does Promote Peace: New Simultaneous Estimates of the Reciprocal Effects of Trade and Conflict." Journal of Peace Research 47(6), 763-774.

Heston, Alan, Robert Summers and Bettina Aten. 2009. Penn World Table Version 6.3. Center for International Comparisons of Production, Income and Prices at the University of Pennsylvania. August. Accessed at http://pwt.econ.upenn.edu/php_site/pwt_index.php.

Hilbe, Joseph. 2007. Negative Binomial Regression. Cambridge, MA: Cambridge University Press.

Hoffman, Bruce. 1998. Recent Trends and Future Prospects of Terrorism in the United States. Santa Monica, CA: RAND.

Hufbauer, Gary C., Jeffrey J. Schott and Barbara Oegg. 2001. "Using Sanctions to Fight Terrorism.” Peterson Institute for International Economics Policy Brief 01-11. November. Accessed at www.iie.com/publications/pb/ pb.cfm? ResearchID $=79$.

Hufbauer, Gary Clyde, Jeffrey Schott, Kimberly Ann Elliott and Barbara Oegg. 2008. Economic Sanctions Reconsidered, 3rd ed. Washington, DC: Institute for International Economics.

Keshk, Omar M. G. 2003. "CDSIMEQ: A Program to Implement Two-Stage Probit Least Squares.” Stata Journal 3(2), 157-167.

Keshk, Omar M. G., Rafael Reuveny and Brian M. Pollins. 2010. "Trade and Conflict: Proximity, Country Size and Measures." Conflict Management and Peace Science 27(1), 3-27.

Krieger, Tim and Daniel Meierrieks. 2010. "What Causes Terrorism?” Public Choice. DOI 10.1007/s11127-010-9601-1.

Krueger, Alan B. 2007. "What Makes a Terrorist: Economics and the Roots of Terrorism.” New York, NY: Cambridge University Press.

Krueger, Alan B. and Jitka Maleckova. 2003. "Education, Poverty and Terrorism: Is There a Causal Connection?” Journal of Economic Perspectives 17(4), 119-144.

LaFree, Gary and Laura Dugan. 2007. "Introducing the Global Terrorism 
Database." Terrorism and Political Violence 19(2), 181-204.

LaFree, Gary, Laura Dugan and Susan Fahey. 2007. "Global Terrorism and Failed

States.”In J. Joseph Hewitt, Jonathan Wilkenfeld and Ted Robert Gurr eds., Peace and Conflict. Boulder, CO: Paradigm.

Li, Quan. 2005. "Does Democracy Promote or Reduce Transnational Terrorist Incidents?" Journal of Conflict Resolution 49(2), 278-297.

Long, J. Scott and Jeremy Freese. 2006. Regression Models for Categorical Dependent Variables Using Stata. 2nd ed. College Station, TX: Stata Press.

Marinov, Nikolay. 2005. "Do Economic Sanctions destabilize Country Leaders?" American Journal of Political Science 49(3), 564-576.

Marshall, Monty and Keith Jaggers. 2007. "POLITY IV Project: Political Regime Characteristics and Transitions, 1800-2006 Dataset Users' Manual." Accessed at www.systemicpeace.org/inscr/p4manualv2006.pdf.

Niblock, Tim. 2001. Pariah States and Sanctions in the Middle East: Iraq, Libya, Sudan. Boulder, CO: Lynne Rienner.

Nossal, Kim Richard. 1989. "International Sanctions as International Punishment.” International Organization 43(2), 301-322.

O'Sullivan, Meghan. 2003. Shrewd Sanctions: Statecraft and State Sponsors of Terrorism. Washington, DC: Brooking Institution Press.

Peksen, Dursun. 2009. "Better or Worse? The Effect of Economic Sanctions on Human Rights." Journal of Peace Research 46(1), 59-77.

Piazza, James A. 2008. "Incubators of Terror: Do Failed States and Failing States Promote Transnational Terrorism?" International Studies Quarterly 52(3), 469-488.

. 2011. "Poverty, Minority Economic Discrimination and Domestic Terrorism.” Journal of Peace Research 48(3), 339-353.

Piazza, James A. and James I. Walsh. 2010. "Physical Integrity Rights and Terrorism.” PS: Political Science and Politics 43(3), 411-414.

Political Instability Task Force. Internal Wars and Failures of Governance, 19552006. Accessed at http://globalpolicy.gmu.edu/pitf/pitfpset.htm.

Rohter, Larry. 1994. "Haiti Embargo hurts Poor, and Nearly Everyone Else." New York Times (August 13).

Rotberg, Robert I. 2002. "Failed States in a World of Terror." Foreign Affairs 81(4), 127-140.

Rowe, David M. 2001. Manipulating the Market: Economic Sanctions, Institutional Change, and the Political Unity of White Rhodesia. Ann Arbor, MI: University of Michigan Press.

Russett, Bruce, John Oneal and David Davis. 1998. "The Third Leg of the Kantian 
Tripod for Peace: International Organizations and Militarized Disputes, 1950-1985." International Organization 52(3), 441-467.

Savun, Burcu and Brian J. Phillips. 2009. "Democracy, Foreign Policy, and Terrorism.” Journal of Conflict Resolution 53(6), 878-904.

Schilmoeller, Janessa. 2012. "Economic Sanctions Harm Iranian People, Not Regime.” New York Times (February 8).

Schmid, Alex P. 1992. "Terrorism and Democracy." Terrorism and Political Violence 4(4), 14-25.

Shea, Patrick E. 2008. "US Foreign Policy and the Resurgence of Economic Sanctions.” Journal of International Relations 10, 70-86.

Solt, Frederick. 2009. "Standardizing the World Income Inequality Database." Social Science Quarterly 90(2), 231-242.

U.S. Census Bureau, Population Division. 2008. International Database (IDB). Accessed at www.census.gov/ipc/www/idb/summaries.html.

Vuong, Quang H. 1989. "Likelihood Ratio Tests for Model Selection and Nonnested Hypothesis.” Econometrica 57(2), 307-333.

Weiss, Thomas G., David Cortright, George A. Lopez and Larry Minear eds. 1997.

Political Gain and Civilian Pain: Humanitarian Impacts of Economic Sanctions. Lanham, MD: Rowman and Littlefield.

Weiss, Thomas. 1999. "Sanctions as a Foreign Policy Tool: Weighing Humanitarian Impulses.” Journal of Peace Research 36(5), 499-514.

Wood, Reed M. 2008. “A Hand upon the Throat of the Nation': Economic Sanctions and State Repression, 1976-2001.” International Studies Quarterly 52(3), 489-513.

Young, Joseph K. and Michael G. Findley. Forthcoming. "Promises and Pitfalls of Terrorism Research.” International Studies Review, 1-39. 